\title{
IMPACT STUDY OF A DUST REMOVAL SYSTEM sciendo ON REDUCTION OF SELECTED HEALTH HAZARDS OF EMPLOYEES IN CARPENTRY
}

doi:10.2478/mape-2018-0041

Date of submission of the article to the Editor: 04/2018

Date of acceptance of the article by the Editor: 07/2018

MAPE 2018, volume 1, issue 1, pp. 323-329

\author{
Dr inż. Krzysztof Michalski \\ Dr Anna Gembalska-Kwiecień \\ Mgr inż. Anna Musioł \\ Silesian University of Technology, Poland
}

Ing. Štefánia Olejárová, PhD.

Technical University Kosice, Slovak Republic

\begin{abstract}
One of the most important aspects related to the proper functioning of prosperous enterprises in the wood industry is to ensure safe and hygienic working conditions. The fulfillment of this condition is obligatory for all workplaces regardless of the field of activity. Due to the specificity of the industry based on wood processing, this industry is inseparably connected with the problem of pollination at workplaces. The chips that are formed during processing make it difficult to work, remain in and around workplaces, creating additional risks and impairing the quality of the manufactured products. It is therefore necessary to apply solutions to eliminate the dust hazard. One of such solutions, belonging to collective protection measures against pollination, are dedusting installations. One of the tools to improve working conditions is mandatory risk assessment. Thanks to its reliable implementation, it is possible to identify hazards occurring at workplaces and take measures to improve working conditions. Proper management of occupational risk is one of the key elements to ensure protection against risks at an appropriate level. The article analyzes the impact of the dedusting installation on the reduction of selected health hazards for employees in the selected carpentry shop.
\end{abstract}

Keywords: dedusting installations, risk assessment, OHS, health hazard

\section{INTRODUCTION - THE CHARACTERISTICS OF THE WORKPLACE IN THE WOODWORKING SHOP REQUIREMENTS}

Featured woodworking factory has an area of $360 \mathrm{~m}^{2}$, it is naturally and mechanically ventilated, lit with natural light $\left(51 \mathrm{~m}^{2}\right.$ of windows $-1.8 \mathrm{~m}^{2}$ on $8 \mathrm{~m}^{2}$ of floor, with $1 \mathrm{~m}^{2}$ of window required for $8 \mathrm{~m}^{2}$ of floor (MPiPS, 1997)) and artificial (500 lux). The temperature in the hall varies from $18^{\circ} \mathrm{C}$ in winter to $26^{\circ} \mathrm{C}$ in the summer. The employee has $12 \mathrm{~m}^{2}$ of machine-free space (with required $2 \mathrm{~m}^{2}$ (MPiPS, 1997)), and $40 \mathrm{~m}^{3}$ of free space from machine tools (with $13 \mathrm{~m}^{3}$ required (MPiPS, 1997)). The width of transitions between machines is min. $1.1 \mathrm{~m}$ (with the required 0.75 (MPiPS, 1997)). A number of personal and collective protection measures are applied.

The following risks were identified in the carpenter's position:

- Fall;

- Damage to the body through moving parts of machine;

- Damage to the body through workpieces;

- Excessive dynamic load;

- Noise;

- Dusting;

- Fire; 
- Electric shock;

- Chemical factorsreferences.tables.

\section{POLLINATION MEASUREMENT BEFORE INSTALLING THE DUST REMOVAL SYSTEM}

To study the level of dustiness (determination of the dust exposure index), one employee was selected, representing the workplace of a carpenter in the examined plant. Air samples taken to determine the concentration of dust at the work of the carpenter were taken in accordance with the guidelines of norm (PKN, 2004). A minimum weight of total dust on the filter at $0.3 \mathrm{mg}$ was assumed. At the time of the measurement, the employee performed typical activities for his station in the following order: transport of items from the warehouse, sawing, planning and milling, grinding of elements, drilling, turning and transport to the warehouse. Samples were taken continuously for six hours. At the time of measurement, five samples were taken (another five filters). The results of the measurements obtained are presented in the table below (Table 1).

Table 1

The result of the sampling measurements before installing the dust removal

\begin{tabular}{|c|c|c|c|}
\hline $\begin{array}{c}\text { Number } \\
\text { of filter }\end{array}$ & $\begin{array}{c}\text { Mass of filter before taking a } \\
\text { sample of dust } \\
{[\mathbf{m g}]}\end{array}$ & $\begin{array}{c}\text { Mass of filter after taking a } \\
\text { sample of dust } \\
{[\mathrm{mg}]}\end{array}$ & $\begin{array}{c}\text { Time of sampling } \\
\text { [min] }\end{array}$ \\
\hline 1 & 0.20 & 1.73 & 45 \\
\hline 2 & 0.20 & 1.02 & 125 \\
\hline 3 & 0.20 & 2.52 & 40 \\
\hline 4 & 0.20 & 2.23 & 35 \\
\hline 5 & 0.20 & 0.96 & 115 \\
\hline
\end{tabular}

Based on formula 1, the total dust concentration was determined $\mathrm{X}_{\mathrm{i}}$.

$$
X_{i}=\frac{\left(m_{2, i}-m_{1, i}\right)}{V_{i}} * 1000\left[\frac{m g}{m^{3}}\right]
$$

where:

$m_{1, i}-$ mass of i-filter before taking a sample of dust [mg],

$m_{2, i}-$ mass of i-filter after taking a sample of dust [mg],

$V_{i}-$ volume of sucked air $\left[\mathrm{dm}^{3}\right]$

The volume of air sucked was calculated based on the formula:

$$
V_{i}=P * t_{i}\left[d m^{3}\right]
$$

where:

$P$ - air flow $\left[\mathrm{dm}^{3} / \mathrm{min}\right]$

$t_{i}=$ time of sampling [min]

The results obtained are shown in Table 2.

Table 2

Determination of dust concentration at the workplace before installing the dust removal system

\begin{tabular}{|c|c|c|c|c|c|}
\hline No. & $\begin{array}{c}\text { Mass of sample of } \\
\text { dust on filter }\left(\mathbf{m}_{\mathbf{2}}-\mathbf{m}_{\mathbf{1}}\right) \\
{[\mathbf{m g}]}\end{array}$ & $\begin{array}{c}\text { Air flow in personal } \\
\mathbf{e x h a u s t e r} \\
{\left[\mathbf{d m}^{\mathbf{3}} \mathbf{m} \mathbf{m} \mathbf{n}\right]}\end{array}$ & $\begin{array}{c}\text { Time of } \\
\text { sampling } \\
{[\mathbf{m i n}]}\end{array}$ & $\begin{array}{c}\text { Volume of } \\
\text { sucked air } \mathbf{V}_{\mathbf{i}} \\
{\left[\mathbf{d m}^{\mathbf{3}}\right]}\end{array}$ & $\begin{array}{c}\text { Dust } \\
\text { concentration } \mathbf{X}_{\mathbf{i}} \\
{\left[\mathbf{m g}_{\mathbf{~}} \mathbf{\mathbf { m } ^ { 3 }} \text { ] }\right.}\end{array}$ \\
\hline 1 & 1.53 & 2 & 45 & 90 & 1.00 \\
\hline 2 & 0.83 & 2 & 125 & 250 & 3.32 \\
\hline 3 & 2.32 & 2 & 40 & 80 & 29.00 \\
\hline 4 & 2.03 & 2 & 35 & 70 & 29.00 \\
\hline 5 & 0,76 & 2 & 115 & 230 & 3.30 \\
\hline
\end{tabular}


Then, using the formula 3 , the dust exposure indicator $C_{w}$ was determined:

$$
\mathrm{C}_{w}=\frac{\sum_{i=1}^{n} X_{i} * t_{i}}{\sum_{i=1}^{n} t_{i}} * \frac{T_{e}}{480}\left[\frac{m g}{m^{3}}\right]
$$

where:

$X_{i}$ - dust concentration in i-sample $\left[\mathrm{mg} / \mathrm{m}^{3}\right]$

$t_{i}$ - time of sampling of i-sample of dust [min]

$n$ - number of samples taken

$T_{e}$ - exposure time [min]

The results are presented in the table below (Table 3).

Table 3

Determination of the dust exposure indicator before installing the dust removal system

\begin{tabular}{|c|c|c|c|c|c|}
\hline No. & $\begin{array}{c}\text { Dust } \\
\text { concentration } \\
\mathbf{X}_{\mathbf{i}}\left[\mathbf{m g} / \mathbf{m}^{3}\right]\end{array}$ & $\begin{array}{c}\text { Time of sampling } \\
\text { of sample of dust } \mathbf{t}_{\mathbf{i}} \\
{[\mathbf{m i n}]}\end{array}$ & $\begin{array}{c}\text { Dust concentration } \\
\text { Time of sampling of } \\
\text { sample of dust }\end{array}$ & $\begin{array}{c}\text { Exposure } \\
\text { time } \mathbf{T}_{\mathbf{e}} \\
{[\mathbf{m i n}]}\end{array}$ & $\begin{array}{c}\text { Dust exposure } \\
\text { indicator } \mathbf{C}_{\mathbf{w}} \\
{\left[\mathbf{m g} / \mathbf{m}^{3}\right]}\end{array}$ \\
\hline 1 & 17.00 & 45 & 765.00 & & \\
\hline 2 & 3.22 & 125 & 415.00 & & \\
\hline 3 & 29,00 & 40 & 1160.00 & & \\
\hline 4 & 29.00 & 35 & 1015.00 & & \\
\hline 5 & 3.30 & 115 & 379.50 & & \\
\hline Sum & & 360 & 3734.50 & 460 & 9.94 \\
\hline
\end{tabular}

The exposure index for wood dust at the workplace of the carpenter in the plant before the application of the dedusting installation is $9.94 \mathrm{mg} / \mathrm{m}^{3}$. The highest acceptable concentration in total dust for wood dust (except hardwood dust, ie beech and oak) is $4 \mathrm{mg} / \mathrm{m}^{3}$ (MPiPS, 2014). The multiplicity of the standard for the result obtained is: $\mathrm{k}=9.94 / 4=2.49$.

The concentration of wood dust on the site in the selected plant exceeds the permissible standard by almost two and a half times.

\section{RISK ASSESSMENT BEFORE INSTALLING THE DUST REMOVAL SYSTEM}

The ability to satisfy the needs of clients (including internal ones, as well as employees of the company) is necessary not only in activities going outside, but also within all organizations (Sitko, 2015). For carpentry workers, the basic need is safety at the workplace. One of the tools to improve working conditions is a compulsory assessment of occupational risk, i.e. the probability of occurrence of undesirable events related to the work performed, causing losses and the occurrence of adverse health effects in the employee (Komisja Europejska, 2000). Thanks to its reliable implementation, it is possible to identify hazards occurring at workplaces and take measures to improve working conditions. Proper management of occupational risk is one of the key elements to ensure protection against risks at an appropriate level.

Table 4 shows the Occupational Risk Assessment Card before using the de-dusting installation. Due to the volume framework of the article, the selected hazards are included in the card. The following markings have been adopted: $\mathrm{C}$ - severity of consequences, $\mathrm{P}$ probability of occurrence, $\mathrm{R}$ - risk, $\mathrm{M}$ - low severity of consequences/unlikely/low risk, S average severity of consequences/likely/medium risk, D - high severity of consequences /highly probable/high risk. 
Table 4

Risk assessment on the workplace of carpenter before installing the dust

\begin{tabular}{|c|c|c|c|c|c|c|c|c|c|c|}
\hline \multirow[t]{2}{*}{ No. } & \multirow[t]{2}{*}{ Danger } & \multirow[t]{2}{*}{$\begin{array}{l}\text { Source of } \\
\text { danger }\end{array}$} & \multirow[t]{2}{*}{$\begin{array}{l}\text { the potential } \\
\text { effects of } \\
\text { the threat }\end{array}$} & \multicolumn{3}{|c|}{$\begin{array}{c}\text { Before } \\
\text { application of } \\
\text { preventive } \\
\text { measures }\end{array}$} & \multirow[t]{2}{*}{$\begin{array}{l}\text { Preventive } \\
\text { measures }\end{array}$} & \multicolumn{3}{|c|}{$\begin{array}{c}\text { After } \\
\text { application of } \\
\text { preventive } \\
\text { measures }\end{array}$} \\
\hline & & & & $\mathrm{C}$ & $\mathrm{P}$ & $\mathrm{R}$ & & $\mathrm{C}$ & $\mathrm{P}$ & $\mathrm{R}$ \\
\hline 1 & Fall & $\begin{array}{l}\text { Slippery, } \\
\text { uneven } \\
\text { surfaces }\end{array}$ & $\begin{array}{l}\text { Bruises, limb } \\
\text { fractures, } \\
\text { concussion }\end{array}$ & $S$ & $S$ & $S$ & $\begin{array}{l}\text { Non-slip } \\
\text { shoes, order at } \\
\text { the workplace }\end{array}$ & Ś & $\mathrm{M}$ & $\mathrm{M}$ \\
\hline 2 & $\begin{array}{l}\text { Damage to } \\
\text { the body } \\
\text { through } \\
\text { moving parts } \\
\text { of machine }\end{array}$ & $\begin{array}{l}\text { No cover or } \\
\text { security, } \\
\text { wrong posture } \\
\text { or hand } \\
\text { positioning }\end{array}$ & $\begin{array}{l}\text { Severe } \\
\text { injuries to } \\
\text { fingers, } \\
\text { hands, face } \\
\text { and head }\end{array}$ & $\mathrm{D}$ & $\mathrm{D}$ & $\mathrm{D}$ & $\begin{array}{l}\text { Use of efficient } \\
\text { protective } \\
\text { covers and } \\
\text { mechanisms, }\end{array}$ & $\mathrm{S}$ & $S$ & S \\
\hline 3 & $\begin{array}{l}\text { Damage to } \\
\text { the body } \\
\text { through } \\
\text { workpieces }\end{array}$ & $\begin{array}{l}\text { Processing of } \\
\text { wooden } \\
\text { elements }\end{array}$ & $\begin{array}{l}\text { Rubbing, } \\
\text { cuts, mainly } \\
\text { hand and } \\
\text { face }\end{array}$ & $S$ & $\mathrm{D}$ & $\mathrm{D}$ & $\begin{array}{l}\text { Adheres to the } \\
\text { station } \\
\text { instructions }\end{array}$ & $\bar{M}$ & $\bar{M}$ & $M$ \\
\hline 4 & $\begin{array}{l}\text { Excessive } \\
\text { dynamic load }\end{array}$ & $\begin{array}{l}\text { Manual } \\
\text { handling of } \\
\text { components } \\
\text { with a weight } \\
\text { exceeding the } \\
\text { norm }\end{array}$ & $\begin{array}{l}\text { Spinal and } \\
\text { joint injuries }\end{array}$ & $\mathrm{D}$ & $\mathrm{D}$ & $\mathrm{D}$ & $\begin{array}{l}\text { Compliance } \\
\text { with lifting } \\
\text { standards }\end{array}$ & $\mathrm{S}$ & $M$ & $M$ \\
\hline 5 & Noise & $\begin{array}{l}\text { Non-use of } \\
\text { hearing } \\
\text { protectors }\end{array}$ & Hearing loss & $\mathrm{D}$ & $\mathrm{D}$ & $\mathrm{D}$ & $\begin{array}{l}\text { Use of hearing } \\
\text { protectors }\end{array}$ & $\mathrm{S}$ & $S$ & $S$ \\
\hline 6 & Dusting & $\begin{array}{l}\text { Mechanical } \\
\text { processing of } \\
\text { wood }\end{array}$ & $\begin{array}{l}\text { Respiratory } \\
\text { diseases }\end{array}$ & $\mathrm{D}$ & $\mathrm{D}$ & D & $\begin{array}{l}\text { Individual } \\
\text { protective } \\
\text { equipment } \\
\text { (masks). The } \\
\text { dedusting } \\
\text { installation will } \\
\text { be introduced }\end{array}$ & - & - & - \\
\hline 7 & Fire & $\begin{array}{l}\text { Placing } \\
\text { flammable } \\
\text { waste in } \\
\text { workstations }\end{array}$ & Burns, death & $\bar{D}$ & $\mathrm{D}$ & $\mathrm{D}$ & $\begin{array}{l}\text { Ongoing } \\
\text { removal of } \\
\text { waste from } \\
\text { workstations }\end{array}$ & $\mathrm{S}$ & $M$ & $M$ \\
\hline 8 & $\begin{array}{l}\text { Electric } \\
\text { shock }\end{array}$ & $\begin{array}{l}\text { Damaged } \\
\text { anti-shock } \\
\text { protection }\end{array}$ & Death & $\mathrm{D}$ & $\mathrm{D}$ & D & $\begin{array}{l}\text { Applying } \\
\text { effective and } \\
\text { effective anti- } \\
\text { shock } \\
\text { protection }\end{array}$ & $\mathrm{M}$ & $M$ & $M$ \\
\hline 9 & $\begin{array}{l}\text { Chemical } \\
\text { factors }\end{array}$ & $\begin{array}{l}\text { Paints, } \\
\text { varnishes, } \\
\text { solvents }\end{array}$ & $\begin{array}{l}\text { Poisoning, } \\
\text { allergies }\end{array}$ & $S$ & $\mathrm{~S}$ & $S$ & $\begin{array}{l}\text { Follow the } \\
\text { guidelines in } \\
\text { the substance } \\
\text { sheets }\end{array}$ & $S$ & $M$ & $M$ \\
\hline
\end{tabular}

On the basis of the occupational risk assessment carried out at the carpenter's workplace in the examined carpentry workshop, it can be concluded that:

1. The source of a significant part of the threats are woodworking machines, whose movable, sharp and protruding parts, when not using appropriate prophylactic measures, can lead to significant bodily injuries. The use of appropriate measures (mainly shields compliant with machine maintenance and technical documentation) limits the probability of an undesirable event and thus the level of risk - from high (unacceptable) to medium (acceptable risk, however, it is still necessary to plan and implement actions that will seek to reduce risk level) or small.

2. An important aspect is the attitude of employees - adherence to job instructions and health and safety regulations is a key element in reducing the level of risk. 
3. One of the most important hazards in the carpenter's work is wood waste (chips) that arise during processing - they can lead to damage and damage to the face and eyes.

4. Pollination is an inseparable threat in the carpenter's work. In the woodworking station, the permissible dust concentration is exceeded two and a half times, which can lead to a number of respiratory diseases (pneumoconiosis, allergies, dermatitis, cancer) and eye diseases (including conjunctivitis) (Kordecka, 1999). In addition, this level of dustiness negatively affects the comfort and quality of work.

\section{CHARACTERISTIC OF THE DUST REMOVAL SYSTEM}

On The basic element of the dust extraction system is a filter that serves to separate dust and chips and sawdust that arise during mechanical woodworking. In the discussed case, a floor filter was installed on the roof of the sawdust tank. The device responsible for transporting dust from filter machines is a fan. The filter capacity was selected for the air demand of all machines working simultaneously. The air demand of machines was calculated based on outlet diameters (openings through which dust and chips are removed during operation) (Juda, 1968).

Due to the machine layout, three extraction lines have been designed. Figure 1 shows the course of these lines.

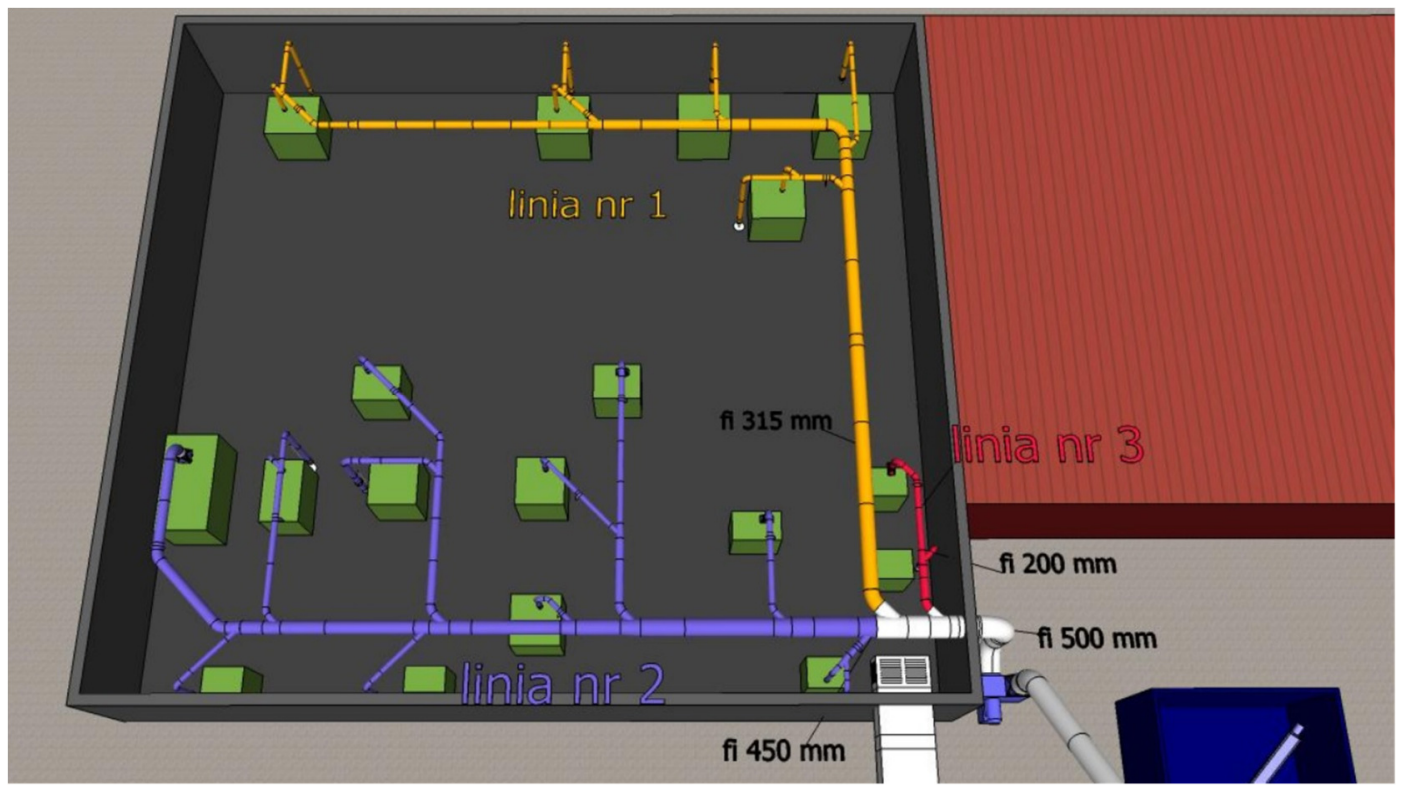

Fig. 1. Route of extraction lines of dust removal system

\section{POLLINATION MEASUREMENT AFTER INSTALLING THE DUST REMOVAL SYSTEM}

After installing the dust removal system, dust measurements were carried out again. The measurement was carried out continuously for 6 hours, in succession up to two filters. The results of these measurements are shown in Table 5.

Table 5

The result of the sampling measurements after installing the dust removal

\begin{tabular}{|c|c|c|c|}
\hline $\begin{array}{c}\text { Number } \\
\text { of filter }\end{array}$ & $\begin{array}{c}\text { Mass of filter before taking a } \\
\text { sample of dust } \\
{[\mathrm{mg}]}\end{array}$ & $\begin{array}{c}\text { Mass of filter after taking a } \\
\text { sample of dust } \\
{[\mathrm{mg}]}\end{array}$ & $\begin{array}{c}\text { Time of sampling } \\
\text { [min] }\end{array}$ \\
\hline 1 & 0.20 & 0.51 & 215 \\
\hline 2 & 0.20 & 0.57 & 145 \\
\hline
\end{tabular}

The dust concentration is shown in Table 6. 
Table 6

Determination of dust concentration at the workplace after installing the dust removal system

\begin{tabular}{|c|c|c|c|c|c|}
\hline No. & $\begin{array}{c}\text { Mass of sample of } \\
\text { dust on filter }\left(\mathbf{m}_{\mathbf{2}}-\mathbf{m}_{\mathbf{1}}\right) \\
{[\mathbf{m g}]}\end{array}$ & $\begin{array}{c}\text { Air flow in personal } \\
\text { exhauster } \\
{\left[\mathbf{d m}^{3} / \mathbf{m i n}\right]}\end{array}$ & $\begin{array}{c}\text { Time of } \\
\text { sampling } \\
{[\mathbf{m i n}]}\end{array}$ & $\begin{array}{c}\text { Volume of } \\
\text { sucked air } \mathbf{V}_{\mathbf{i}} \\
{\left[\mathbf{d m}^{3}\right]}\end{array}$ & $\begin{array}{c}\text { Dust } \\
\text { concentration } \mathbf{X}_{\mathbf{i}} \\
{\left[\mathbf{m g}_{\mathbf{~}} \mathbf{m}^{3}\right]}\end{array}$ \\
\hline 1 & 0.31 & 2 & 215 & 430 & 0.72 \\
\hline 2 & 0.37 & 2 & 145 & 290 & 1.28 \\
\hline
\end{tabular}

The dust exposure indicator was then determined. The results are presented in Table 7.

Table 7

Determination of the dust exposure indicator after installing the dust removal system

\begin{tabular}{|c|c|c|c|c|c|}
\hline No. & $\begin{array}{c}\text { Dust } \\
\text { concentration } \mathbf{X}_{\mathbf{i}} \\
{\left[\mathbf{m g} / \mathbf{m}^{3}\right]}\end{array}$ & $\begin{array}{c}\text { Time of sampling of } \\
\text { sample of dust } \mathbf{t}_{\mathbf{i}} \\
{[\mathrm{min}]}\end{array}$ & $\begin{array}{c}\text { Dust concentration * } \\
\text { Time of sampling of } \\
\text { sample of dust }\end{array}$ & $\begin{array}{c}\text { Exposure } \\
\text { time } \mathbf{T}_{\mathbf{e}} \\
{[\mathbf{m i n}]}\end{array}$ & $\begin{array}{c}\text { Dust exposure } \\
\text { indicator } \mathbf{C}_{\mathbf{w}} \\
{\left[\mathrm{mg} / \mathbf{m}^{3}\right]}\end{array}$ \\
\hline 1 & 0.72 & 215 & 154.80 & & \\
\hline 2 & 1.28 & 145 & 185.60 & & \\
\hline Sum & & 360 & 340.40 & 460 & 0.91 \\
\hline
\end{tabular}

The exposure index for wood dust at the workplace in the tested plant after the application of the dedusting installation is $0.91 \mathrm{mg} / \mathrm{m}^{3}$. The multiplicity of the standard for the result obtained is: $\mathrm{k}=0.91 / 4=0.23$.

After using the dedusting installation, the concentration of wood dust on the site in the selected plant is almost four and a half times below the permissible standard.

\section{RISK ASSESSMENT AFTER INSTALLING THE DUST REMOVAL SYSTEM}

After installing the dedusting installation, occupational risk assessment was carried out again based on norm (PKN, 2011). Table 8 summarizes the results of the risk assessment, with only those hazards that were affected by the installation of the dedusting installation.

Table 8

Risk assessment on the workplace of carpenter before installing the dust removal system

\begin{tabular}{|c|c|c|c|c|c|c|c|c|c|c|}
\hline \multirow[t]{2}{*}{ No. } & \multirow[t]{2}{*}{ Danger } & \multirow[t]{2}{*}{$\begin{array}{c}\text { Source of } \\
\text { danger }\end{array}$} & \multirow[t]{2}{*}{$\begin{array}{l}\text { the potential } \\
\text { effects of } \\
\text { the threat }\end{array}$} & \multicolumn{3}{|c|}{$\begin{array}{c}\text { Before } \\
\text { application of } \\
\text { preventive } \\
\text { measures }\end{array}$} & \multirow[t]{2}{*}{$\begin{array}{l}\text { preventive } \\
\text { measures }\end{array}$} & \multicolumn{3}{|c|}{$\begin{array}{c}\text { After } \\
\text { application of } \\
\text { preventive } \\
\text { measures }\end{array}$} \\
\hline & & & & C & $P$ & $\mathrm{R}$ & & $\mathrm{C}$ & $P$ & $\mathrm{R}$ \\
\hline 3 & $\begin{array}{l}\text { Damage to } \\
\text { the body } \\
\text { through } \\
\text { workpieces }\end{array}$ & $\begin{array}{l}\text { Processing of } \\
\text { wooden } \\
\text { elements }\end{array}$ & $\begin{array}{l}\text { Rubbing, } \\
\text { cuts, mainly } \\
\text { hand and } \\
\text { face }\end{array}$ & $\mathrm{D}$ & $\mathrm{D}$ & $\mathrm{D}$ & $\begin{array}{l}\text { Dust } \\
\text { extraction } \\
\text { system } \\
\text { Use of safety } \\
\text { goggles }\end{array}$ & $\bar{M}$ & $\bar{M}$ & $\bar{M}$ \\
\hline 6 & Dusting & $\begin{array}{l}\text { Mechanical } \\
\text { processing of } \\
\text { wood }\end{array}$ & $\begin{array}{l}\text { Respiratory } \\
\text { diseases }\end{array}$ & D & D & D & $\begin{array}{l}\text { The dust } \\
\text { removal } \\
\text { system }\end{array}$ & $M$ & $M$ & M \\
\hline 7 & Fire & $\begin{array}{l}\text { Placing } \\
\text { flammable } \\
\text { waste }\end{array}$ & Burns, death & $\mathrm{D}$ & $\mathrm{D}$ & $\mathrm{D}$ & $\begin{array}{ll} & \text { The dust } \\
\text { removal } & \\
\text { system } & \end{array}$ & $\bar{M}$ & $M$ & $M$ \\
\hline
\end{tabular}

\section{CONCLUSION}

The installation has effectively reduced the level of occupational risk associated with hazards such as dust, fire and bodily harm caused by workpieces. The use of the installation caused a nearly eleven-fold reduction in the exposure rate for wood dust. A well-functioning installation reduced the likelihood of a fire. The protective measure applied has contributed to reducing the level of occupational risk associated with the damage to the workpieces and waste generated during this treatment. 


\section{ACKNOWLEDGEMENTS}

The paper is the result of statutory research carried out at the Institute of Production Engineering at the Faculty of Organization and Management of the Silesian University of Technology as part of a project number 13/030/BK_18/0039 called "Development of intelligent production methods as well as work and life environments in the context of production engineering challenges".

\section{REFERENCES}

Juda, J. (1968). Pomiary zapylenia i technika odpylania. Warszawa: Wydawnictwa Naukowo Techniczne.

Komisja Europejska, (2000). Dyrektywa 2000/54/WE Parlamentu Europejskiego oraz Rady Europejskiej z dnia 18 września 2000 r. dotycząca ochrony pracowników przed ryzykiem związanym z narażeniem na czynniki biologiczne w miejscu pracy. Official Journal of the European Communities, L. 262/21, Brussels 2000.

Kordecka, D. (1999). Bezpieczeństwo Pracy i Ergonomia. Tom 1. Warszawa: Wydawnictwo CIOP.

Ministerstwo Pracy i Polityki Społecznej, (1997). Rozporządzenie Ministra Pracy i Polityki Socjalnej z dnia 26 września 1997 r. w sprawie ogólnych przepisów bezpieczeństwa i higieny pracy (Dz. U. 2003, nr 169, poz. 1650 ze zm.).

Ministerstwo Pracy i Polityki Społecznej, (2014). Rozporządzenie Ministra Pracy i

PKN, (2004). PN-Z-04008-7:Az1:2004 - Ochrona czystości powietrza. Pobieranie próbek. Zasady pobierania próbek powietrza w środowisku pracy i interpretacji wyników.

PKN, (2011). PN-N-18002:2011 - systemy zarządzania bezpieczeństwem i higieną pracy. Ogólne wytyczne do oceny ryzyka zawodowego.

Polityki Społecznej z dnia 6 czerwca 2014 w sprawie najwyższych dopuszczalnych stężeń i natężeń czynników szkodliwych dla zdrowia w środowisku pracy (Dz. U. 2014, poz. 817).

Sitko, J. (2015). The intelligent process of initiating new product in aspect problems of management. In: 15th International Multidisciplinary Scientific GeoConference SGEM 2015. Ecology, economics, education and legislation, 18-24, June, 2015, Albena, Bulgaria. Conference proceedings. Vol. 3. Environmental economics, education \& accreditation in geosciences. Sofia : STEF92 Technology, 2015, pp. 689-696. 